\title{
THE EFFECT OF MINERAL FERTILIZATION ON FUNGI COLONIZING POTATO (Solanum tuberosum L.) TUBERS AFTER HARVEST AND AFTER STORAGE
}

\author{
Bożena Cwalina-Ambroziak ${ }^{1}$, Bożena Bogucka²
}

\begin{abstract}
${ }^{1}$ Department of Phytopathology and Entomology, University of Warmia and Mazury, Prawocheńskiego 17, 10-720 Olsztyn, Poland
${ }^{2}$ Department of Agrotechnology and Crop Management, University of Warmia and Mazury, Oczapowskiego 8, 10-719 Olsztyn, Poland e-mail: bambr@uwm.edu.pl
\end{abstract}

Received: 30.03 .2009

\section{Abstract}

The paper presents the results of a three-year exact experiment conducted in Bałcyny, in which a late potato cultivar, Jasia, was grown. The objective of the study was to determine the effect of different levels of mineral fertilization: $\mathrm{A}(\mathrm{N} 80 \mathrm{~kg}$ $\left.\times \mathrm{ha}^{-1} \mathrm{P} 80 \mathrm{~kg} \times \mathrm{ha}^{-1} \mathrm{~K} 120 \mathrm{~kg} \times \mathrm{ha}^{-1}\right)$ and B $\left(\mathrm{N} 120 \mathrm{~kg} \times \mathrm{ha}^{-1}\right.$ $\mathrm{P} 144 \mathrm{~kg} \times \mathrm{ha}^{-1} \mathrm{~K} 156 \mathrm{~kg} \times \mathrm{ha}^{-1}$ ), and foliar fertilization (Basfoliar 12-4-6, ADOB Mn and Solubor DF) on the quantitative and qualitative composition of fungal populations colonizing potato tubers. Fungi were isolated immediately after harvest and after a five-month storage period. After seven days of incubation, fungal colonies were transferred onto agar slants for microscopic identification.

Over the entire experimental period, more pathogenic fungi were obtained from potato tubers analyzed after storage (62.9\% of the total fungal population after storage) than from those analyzed immediately after harvest $(39.1 \%)$, and the greatest number of fungi was reported in 2004. Rhizoctonia solani was isolated most frequently, followed by Colletotrichum coccodes and Alternaria alternata. Pathogens of the genus Fusarium and the species Helminthosporium solani were not numerous. In the treatment A with soil mineral fertilization with lower NPK rates, larger numbers of pathogenic fungi were noted in 2004 after harvest and after five-month storage, and in 2005 after harvest. At the remaining dates of analysis, pathogens were more frequently isolated from potato tubers in experimental variant B with higher NPK rates.

Immediately after harvest, the highest number of pathogenic fungi was isolated in the treatment with foliar application of ADOB Mn and Basfoliar 12-4-6. After five-month storage, pathogens most often colonized potato tubers in experimental variant B with foliar application of Solubor DF, Solubor DF and ADOB Mn, and in experimental variant $\mathrm{A}$ with a combination of fertilizers. In the other fertilization variants, including in the control treatment, the population size of pathogenic agents remained at a similar level.

Key words: potato tubers, mineral fertilization, foliar fertilization, fungi

\section{INTRODUCTION}

Multi-component fertilizers applied to leaves are an important element of modern potato production technologies (Honeycut t et al. 1996; Haberl a n d, 2000; B o l i g to w a , 2003). Under stress conditions, such as drought or excessive soil acidification, foliar fertilization can replace traditional organic and mineral fertilization. Apart from its yield-forming effect, foliar fertilization also affects the quality of potato tubers (it contributes to an increase in starch and vitamin $\mathrm{C}$ content and influences protein concentration and quality) and their storage life (K o z e ra et al. 2006).

In addition, mixed fertilizers applied to leaves determine the composition of pathogenic and saprotrophic fungal communities colonizing the aboveground parts of potato plants. Kaps a (2002) demonstrated that the foliar application of Insol 7 to potato plants enabled to decrease the rate of fungicides in the control of $P$. infestans. According to $\mathrm{O}$ s o w s k i (2005), the combined Basfoliar 12-4-6 and fungicide treatment helped to reduce the severity of infection caused by fungi of the genus Alternaria. A previous study conducted by the author of this paper $(\mathrm{C}$ w a l $\mathrm{i}$ $\mathrm{n}$ a-A m b r o ziak et al. 2007) produced ambiguous results with regard to the effect of foliar fertilizers on the frequency of occurrence of pathogens in the phyllosphere of potato plants. Foliar application of fertilizers also alters the composition of fungal communities colonizing potato tubers (Kurzawińska, 1997; $\mathrm{Rębacz}$ and B orówczak, 2007).

The objective of the present laboratory study was to determine the effect of mineral soil fertilization and of foliar fertilization of potatoes on the structure of fungal communities colonizing tubers directly after harvest and after five-month storage. 


\section{MATERIALS AND METHODS}

The experimental materials comprised potato tubers of late cultivar Jasia, harvested during a three-year experiment established in 2004 (investigation period 2004-2006) at the Agricultural Experimental Station in Bałcyny, on gray-brown podsolic soil developed from light silty loam, of complex 4 class III, in four replications. Tillage treatments and agricultural measures (as recommended by the Institute of Soil Science and Plant Cultivation in Puławy) as well as the methods of plant protection against agrophages (as recommended by the Institute of Plant Protection in Poznań) were identical in all experimental plots.

The following experimental factors were considered:

I - levels of mineral fertilization:

A (N $\left.80 \mathrm{~kg} \times \mathrm{ha}^{-1} \mathrm{P} 80 \mathrm{~kg} \times \mathrm{ha}^{-1} \mathrm{~K} 120 \mathrm{~kg} \times \mathrm{ha}^{-1}\right)$,

B (N $120 \mathrm{~kg} \times \mathrm{ha}^{-1}$ P $\left.144 \mathrm{~kg} \times \mathrm{ha}^{-1} \mathrm{~K} 156 \mathrm{~kg} \times \mathrm{ha}^{-1}\right)$,

II - foliar fetilization:

a (Basfoliar 12-4-6 - 81× ha $\left.^{-1}\right)$,

b (ADOB Mn $-41 \times$ ha $\left.^{-1}\right)$,

c (Solubor DF $-21 \times$ ha $^{-1}$ ),

d (ADOB Mn $-21 \times$ ha $^{-1}+$ Solubor DF $-11 \times$ ha $\left.^{-1}\right)$,

e (ADOB Mn $-21 \times$ ha $^{-1}+$ Basfoliar 12-4-6 - 4 $1 \times$ ha $\left.^{-1}\right)$

f (Basfoliar 12-4-6 - 4 1 $\times$ ha $^{-1}+$ Solubor DF - 1 $\left.1 \times \mathrm{ha}^{-1}\right)$,

g (Basfoliar 12-4-6 - $2.7 \mathrm{l} \times \mathrm{ha}^{-1}+$ ADOB Mn

$-1.31 \times$ ha $^{-1}+$ Solubor DF $-0.71 \times$ ha $^{-1}$ )

$\mathrm{h}$ (control treatment, no foliar fertilization).

Laboratory samples consisted of 30 tubers collected randomly in four replications per treatment, directly after harvest and after five-month storage at $5^{\circ} \mathrm{C}$. Following disinfection with $50 \%$ ethanol and $1 \%$ sodium hypochlorite, blocks $(0.5 \times 0.5 \times 1.5 \mathrm{~cm})$ were cut from tubers and placed on PDA medium. After seven days of incubations, fungal colonies were inoculated onto agar slants for later microscopic iden- tification according to keys and monographs (A r x , 1970; B o o th, 1971; Ellis, 1971; D o m s ch et al. 1980).

The results were processed statistically and subjected to variance analysis (STATISTICA ${ }^{\circledR} 8.02008$ ), the Duncan's test $(\mathrm{p}=0.01)$ was used for comparison of the averages.

\section{RESULTS AND DISCUSSION}

The fungal population (1809 isolates) was represented by 31 species and yeast-like fungi and nonsporulating fungi (Tab. 2, 3). More fungi (by 9.3\%) were isolated from newly-harvested tubers, compared with tubers stored for five months. However, the proportion of pathogens was higher in stored tubers, reaching $88.2 \%, 48.0 \%$ and $63.1 \%$ in the successive years of the study (Fig. 1). The species isolated most frequently over the entire experimental period was Rhizoctonia solani, followed by Colletotrichum coccodes, which was isolated primarily in the first and third year, with single isolates obtained in the second year. Alternaria alternata was less abundant, but it colonized potato tubers in all analyzed periods, reaching the highest abundance in the second year after five-month storage. High precipitation rates and moderate temperatures noted over the growing seasons of 2004 and 2006 probably contributed to frequent infections caused by $R$. solani, whereas weather conditions in 2005.

(Tab. 1) stimulated invasions by fungi of the genus Alternaria, which is consistent with the findings of other authors (C z a j k a et al. 1999; B e r n a t, 2005; Repsiene and Mineikiene, 2006). The rate of potato tuber colonization by the fungus $C$. coccodes was the same (15\%) at both dates of analysis, while $R$. solani was isolated more frequently after storage (34\%) than after harvest (20.4\%) (Tab. 2, 3). The other potentially pathogenic fungi of the genus Fusarium (F. culmorum, $F$. concolor, $F$. oxysporum and $F$. poae which colonized tubers in all analyzed periods (except

Table 1

Meteorological data according to the Bałcyny Meteorological Station.

\begin{tabular}{|c|c|c|c|c|c|c|c|c|}
\hline \multirow{2}{*}{ Month } & \multicolumn{3}{|c|}{ Mean monthly temperature $\left({ }^{\circ} \mathrm{C}\right)$} & \multirow{2}{*}{$\begin{array}{c}\text { mean for } \\
1960-90\end{array}$} & \multicolumn{3}{|c|}{ Mean monthly rainfall (mm) } & \multirow{2}{*}{$\underset{1960-90}{\sum \text { rainfall }}$} \\
\hline & 2004 & 2005 & 2006 & & 2004 & 2005 & 2006 & \\
\hline May & 11.0 & 12.5 & 12.5 & 12.4 & 87.1 & 68.2 & 93.2 & 56.7 \\
\hline June & 14.5 & 14.9 & 16.0 & 15.7 & 90.6 & 35.4 & 83.5 & 68.3 \\
\hline July & 16.2 & 18.9 & 21.0 & 15.3 & 78.8 & 83.9 & 27.1 & 81.3 \\
\hline August & 18.2 & 16.8 & 17.3 & 17.9 & 89.3 & 39.6 & 141.7 & 78.1 \\
\hline
\end{tabular}




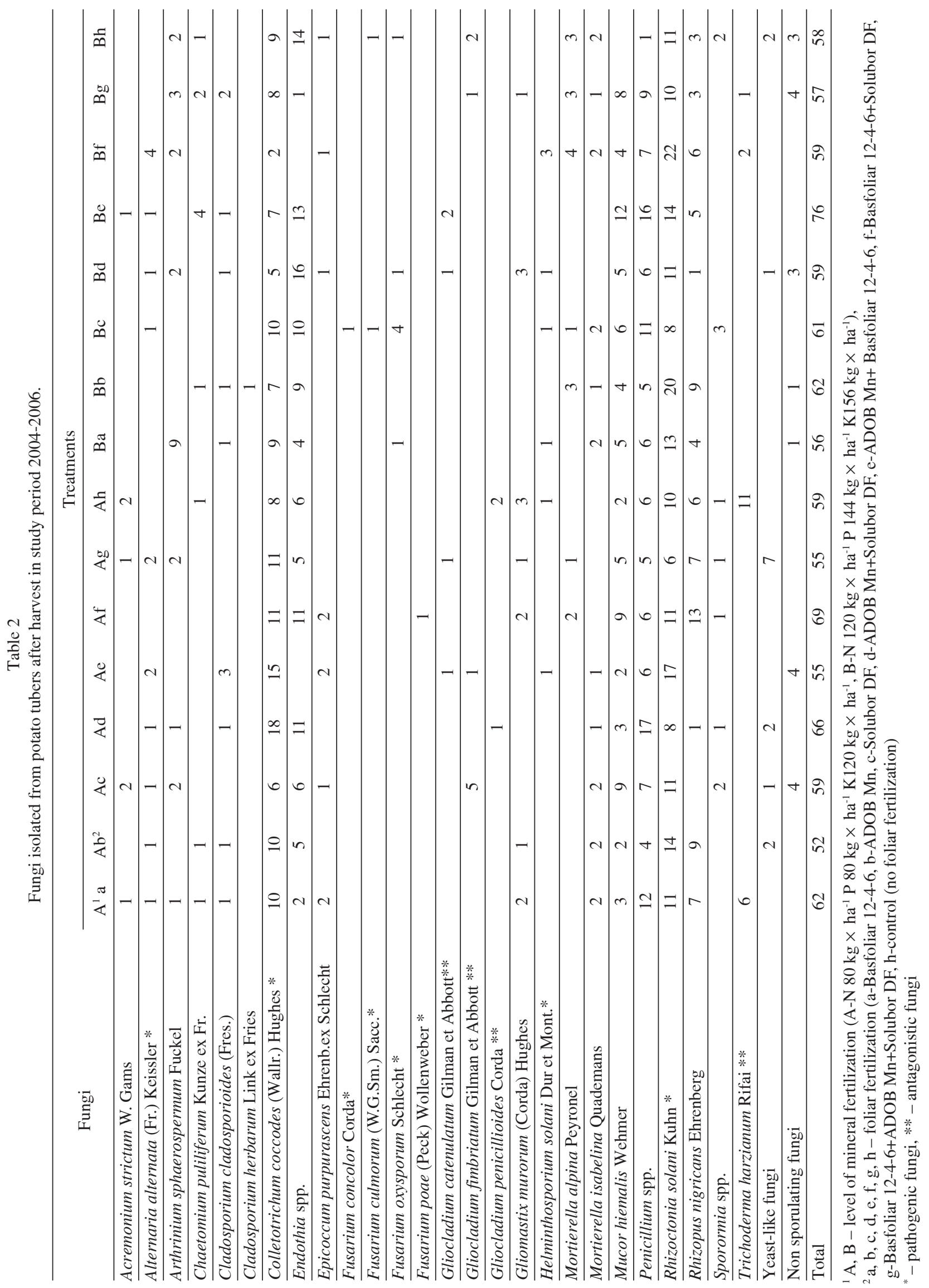




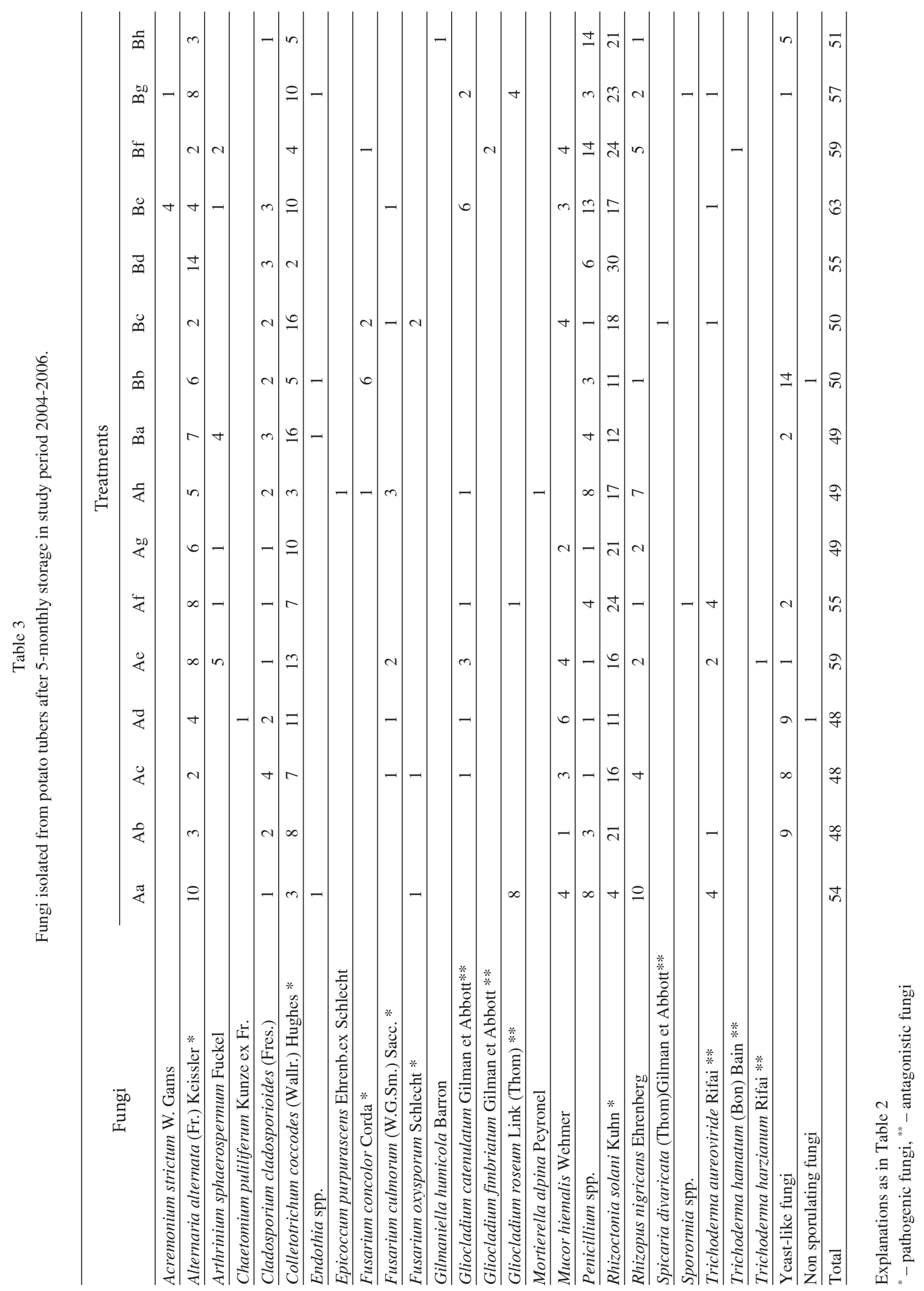


for the year 2006 directly after harvest) constituted less than $4 \%$ of all isolates, and Helminthosporium solani accounted for only $1 \%$ of the total fungal population. The above species are considered typical potato pathogens (W e b e r, 1990; K u r z a w i ń s k a, 1997; Cwalina-A mbroziak, 2002).

An analysis of the levels of mineral soil fertilization showed that more pathogens were isolated in treatment A with lower NPK rates $\left(\mathrm{N}-80 \mathrm{~kg} \times \mathrm{ha}^{-1}\right.$, $\left.\mathrm{P}-80 \mathrm{~kg} \times \mathrm{ha}^{-1}, \mathrm{~K}-120 \mathrm{~kg} \times \mathrm{ha}^{-1}\right)$ in 2004 both after harvest and after storage and in 2005 after harvest, and in treatment $\mathrm{B}$ with higher NPK rates $(\mathrm{N}-120 \mathrm{~kg} \times$ $\left.\mathrm{ha}^{-1}, \mathrm{P}-144 \mathrm{~kg} \times \mathrm{ha}^{-1}, \mathrm{~K}-156 \mathrm{~kg} \times \mathrm{ha}^{-1}\right)$ in the other experimental periods (Fig. 1). C z a j k a et al. (1999) pointed to a significant impact of excessive nitrogen fertilization on the stronger infection of potato tubers by pathogenic fungi. The most abundant saprotrophic fungi were members of the order Mucorales and of the genus Penicillium. In the present study, they were more frequently isolated from tubers after harvest $(19.5 \%$ and $12.8 \%$ respectively) than after storage $(7.8 \%$ and $10.1 \%$ ) (Tab. 2, 3). Differences in the abundance of these fungi between particular fertilization treatments were non-significant, except for Mucorales after storage (Tab. 4). Fungi, represented by species of the genera Gliocladium, Paecilomyces and Trichoderma, were most frequently isolated from stored tubers in the second year of the study $-7.7 \%$ of all isolates (Fig. 1). The least pathogens were obtained during the above growing season. The above antagonistic microorganisms contribute to reducing of pathogenic fungi population (H o i t i n k and B o e h m, 1999; P a s t u c h a, 1999). As regards the levels of NPK fertilization, more fungi were isolated from treatment "A", with a lower fertilization level, at both dates of analysis.

The present study revealed that the structure of pathogenic fungal communities colonizing potato tubers was affected by foliar fertilization. The most pathogens were isolated from newly-harvested tubers in treatment Ae, where the foliar fertilizers ADOB $\mathrm{Mn}$ and Basfoliar were applied (63.6\% of all fungi in this treatment). Fungal pathogens were less abundant in treatment $\mathrm{Ab}$ with $\mathrm{ADOB} \mathrm{Mn}$ and in treatment $\mathrm{Bf}$ with Basfoliar 12-4-6 and Solubor DF (approx. 48\%) (Fig. 2). In the remaining treatments with foliar fertilization, the abundance of pathogens colonizing tubers was at a comparable, low level of $30 \%$. After storage the largest fungal population ( $82 \%$ to $85.7 \%$ ) was reported in treatments Bc, Bd (ADOB Mn + Solubor DF) and $\mathrm{Ag}$ (combined fertilization) (Fig. 3). In the control

Table 4

Most frequently isolated fungi from potato tubers (mean numbers of isolates for years).

\begin{tabular}{|c|c|c|c|c|c|c|c|c|}
\hline \multirow[b]{2}{*}{ Treatments } & \multicolumn{4}{|c|}{ After harvest } & \multicolumn{4}{|c|}{ After storage } \\
\hline & pathogens & antagonists & Mucorales & $\begin{array}{l}\text { Penicillium } \\
\text { spp. }\end{array}$ & pathogens & antagonists & Mucorales & $\begin{array}{l}\text { Penicillium } \\
\text { spp. }\end{array}$ \\
\hline $\mathrm{Aa}$ & $7.00 \mathrm{a}^{3}$ & $2.00 \mathrm{ab}$ & $4.00 \mathrm{a}$ & $4.33 \mathrm{a}$ & $6.00 \mathrm{~b}$ & $4.00 \mathrm{a}$ & $4.67 \mathrm{a}$ & $2.67 \mathrm{a}$ \\
\hline $\mathrm{Ab}$ & $8.33 \mathrm{a}$ & $0 \mathrm{~b}$ & $4.33 \mathrm{a}$ & $1.33 \mathrm{a}$ & $10.67 \mathrm{ab}$ & $0.33 \mathrm{~b}$ & $0.33 \mathrm{ab}$ & $1.00 \mathrm{a}$ \\
\hline $\mathrm{Ac}$ & $6.00 \mathrm{a}$ & $1.67 \mathrm{ab}$ & $3.67 \mathrm{a}$ & $2.33 \mathrm{a}$ & $9.00 \mathrm{ab}$ & $0.33 \mathrm{~b}$ & $2.33 \mathrm{ab}$ & $0.33 \mathrm{a}$ \\
\hline Ad & $9.00 \mathrm{a}$ & $0.33 \mathrm{~b}$ & $1.67 \mathrm{a}$ & $5.67 \mathrm{a}$ & $9.00 \mathrm{ab}$ & $0.33 \mathrm{~b}$ & $2.00 \mathrm{ab}$ & $0.33 \mathrm{a}$ \\
\hline $\mathrm{Ae}$ & $11.33 \mathrm{a}$ & $0.67 \mathrm{~b}$ & $1.00 \mathrm{a}$ & $2.00 \mathrm{a}$ & $13.00 \mathrm{ab}$ & $2.00 \mathrm{ab}$ & $2.00 \mathrm{ab}$ & $0.33 \mathrm{a}$ \\
\hline Af & $7.67 \mathrm{a}$ & $0 \mathrm{~b}$ & $8.00 \mathrm{a}$ & $2.00 \mathrm{a}$ & $13.00 \mathrm{ab}$ & $2.00 \mathrm{ab}$ & $0.33 \mathrm{ab}$ & $1.33 \mathrm{a}$ \\
\hline $\mathrm{Ag}$ & $6.33 \mathrm{a}$ & $0.33 \mathrm{~b}$ & $4.33 \mathrm{a}$ & $1.67 \mathrm{a}$ & $14.00 \mathrm{a}$ & $0 \mathrm{~b}$ & $1.33 \mathrm{ab}$ & $0.33 \mathrm{a}$ \\
\hline $\mathrm{Ah}$ & $6.00 \mathrm{a}$ & $4.33 \mathrm{a}$ & $2.67 \mathrm{a}$ & $2.00 \mathrm{a}$ & $9.67 \mathrm{ab}$ & $0.33 \mathrm{~b}$ & $2.67 \mathrm{ab}$ & $2.67 \mathrm{a}$ \\
\hline $\mathrm{Ba}$ & $8.00 \mathrm{a}$ & $0 \mathrm{~b}$ & $3.67 \mathrm{a}$ & $2.00 \mathrm{a}$ & $11.67 \mathrm{ab}$ & $0 \mathrm{~b}$ & $0 \mathrm{~b}$ & $1.33 \mathrm{a}$ \\
\hline $\mathrm{Bb}$ & $9.00 \mathrm{a}$ & $0 \mathrm{~b}$ & $5.67 \mathrm{a}$ & $1.67 \mathrm{a}$ & $9.33 \mathrm{ab}$ & $0 \mathrm{~b}$ & $0.33 \mathrm{ab}$ & $1.00 \mathrm{a}$ \\
\hline $\mathrm{Bc}$ & $8.67 \mathrm{a}$ & $0 \mathrm{~b}$ & $3.00 \mathrm{a}$ & $3.67 \mathrm{a}$ & $13.67 \mathrm{a}$ & $0.67 \mathrm{ab}$ & $1.33 \mathrm{ab}$ & $0.33 \mathrm{a}$ \\
\hline $\mathrm{Bd}$ & $6.33 \mathrm{a}$ & $0.33 \mathrm{~b}$ & $2.00 \mathrm{a}$ & $2.00 \mathrm{a}$ & $15.33 \mathrm{a}$ & $0 \mathrm{~b}$ & $0 \mathrm{~b}$ & $2.00 \mathrm{a}$ \\
\hline $\mathrm{Be}$ & $7.33 \mathrm{a}$ & $0.67 \mathrm{~b}$ & $5.67 \mathrm{a}$ & $5.33 \mathrm{a}$ & $10.67 \mathrm{ab}$ & $2.33 \mathrm{ab}$ & $1.00 \mathrm{ab}$ & $4.33 \mathrm{a}$ \\
\hline $\mathrm{Bf}$ & $9.33 \mathrm{a}$ & $0.67 \mathrm{~b}$ & $6.33 \mathrm{a}$ & $2.33 \mathrm{a}$ & $10.33 \mathrm{ab}$ & $1.00 \mathrm{ab}$ & $3.00 \mathrm{ab}$ & $4.67 \mathrm{a}$ \\
\hline $\mathrm{Bg}$ & $6.00 \mathrm{a}$ & $0.67 \mathrm{~b}$ & $4.00 \mathrm{a}$ & $3.00 \mathrm{a}$ & $13.67 \mathrm{a}$ & $2.33 \mathrm{ab}$ & $0.67 \mathrm{ab}$ & $1.00 \mathrm{a}$ \\
\hline $\mathrm{Bh}$ & $7.33 \mathrm{a}$ & $0.67 \mathrm{~b}$ & $2.67 \mathrm{a}$ & $0.33 \mathrm{a}$ & $9.67 \mathrm{ab}$ & $0 \mathrm{~b}$ & $0.33 \mathrm{ab}$ & $4.67 \mathrm{a}$ \\
\hline
\end{tabular}

Explanations as in Table 2

${ }^{3}$ means with the same letter do not differ significantly (Duncan's test, $\mathrm{p}=0.01$ ) 


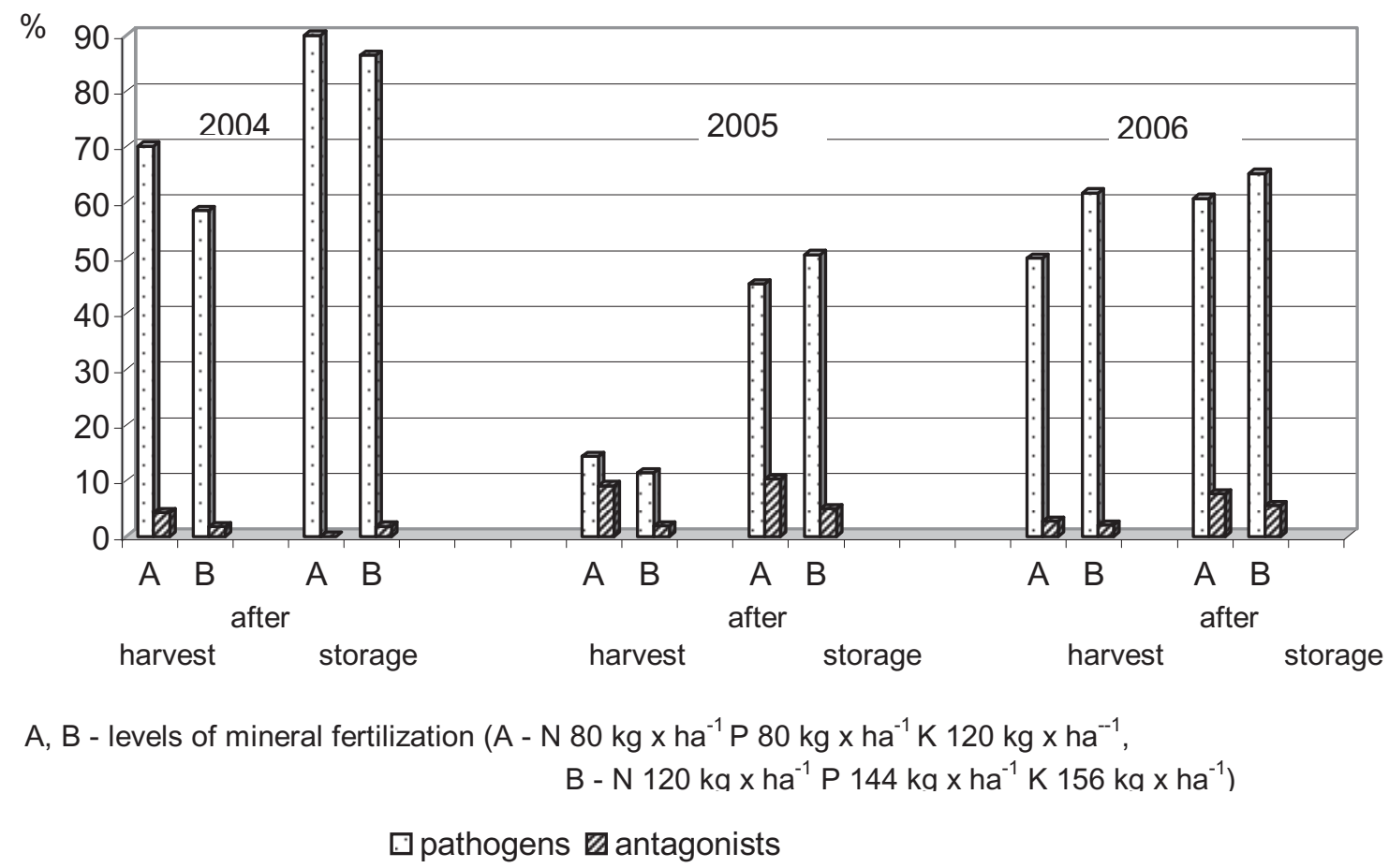

Fig. 1. Fungi isolted from potato tubers during investigation.

treatment, pathogens constituted less than $60 \%$ of all isolates. The fewest colonies of fungi responsible for potato diseases were noted in treatment $\mathrm{Aa}$ (Basfoliar 12-4-6 - 33.3\%) (Fig. 3); the differences in numbers of pathogens were significant as compared to combinations $\mathrm{Ag}, \mathrm{Bc}, \mathrm{Bd}$ and $\mathrm{Bg}$ (Tab. 1). Other authors demonstrated that neither Basfoliar $36 \mathrm{E}$ and ADOB $\mathrm{Mn}\left(\mathrm{J}\right.$ a b ł o ń s k i , 2003) nor $\mathrm{CuCO}_{3}$ applied to leaves (Szutkowska and Lutomirska, 2002) influenced the severity of potato infestation by Streptomyces scabies.

An analysis of pathogen species colonizing newly-harvested tubers indicated that the dominant species, $R$. solani, constituted from $10.9 \%$ in treatment $\mathrm{Ag}$ to $37.3 \%$ in treatment $\mathrm{Bf}$ (Fig. 2). In general, more isolates of this fungus were obtained in treatment $\mathrm{B}$ than in treatment A (except for treatments with Solubor DF, and with ADOB Mn and Basfoliar 12-4-6). As regards stored tubers, the population size of $R$. solani was at a similar level in both treatments with mineral soil fertilization, $\mathrm{A}$ and $\mathrm{B}$, except for the treatment with foliar application of ADOB Mn and for the treatment with combined foliar fertilizers, where more pathogens were isolated following the application of higher rates of mineral soil fertilizers. H o n e y c u t t et al. (1996) demonstrated that nitrogen fertilization at a rate of 0 to $250 \mathrm{~kg} \times \mathrm{ha}^{-1}$ did not affect the severity of plant infection by the above pathogen. R i t c h i e et al. (2006) conducted an in vitro study in which potassium was added to PDA medium and found that this macronutrient had an inhibitory effect on mycelium growth as well as on the production and germination of sclerotia. Rę b acz and B orówczak (2007) demonstrated that foliar fertilization with Mikrosol reduced the level of tuber infection by $R$. solani.

Mineral NPK fertilization and foliar application of fertilizers affected also the abundance of the fungus C. coccodes which colonized both newly-harvested and stored tubers. This pathogen is known to infest potato tubers (accounting for up to $90 \%$ of all fungal isolates - Tsror /Lahim/ et al. 1999), but also roots, stolons and stems (A n d riv o n et al. 1998). In the present experiment, this species was isolated more frequently from tubers in treatment A (with lower mineral fertilization levels) than in treatment B (with higher fertilization levels), with a few exceptions. Its greatest abundance was noted in newly-harvested tubers in treatment $\mathrm{Ad}$ (27.3\%) (Fig. 2), and in stored tubers in treatments $\mathrm{Ba}$ and $\mathrm{Bc}$ (these two treatments were exceptional) (Fig. 3 ). The interpretation of the obtained results suggests a lower infection rate in treatments with higher levels of nitrogen fertilization. Our data are consistent with the findings of other authors (D a v i s, 1981; Z a r z y c k a , 1990) who observed higher rates of $C$. coccodes infection in potato plants grown in nitrogen-deficient soil, in comparison with soil fertilized with adequate amounts of nitrogen. 


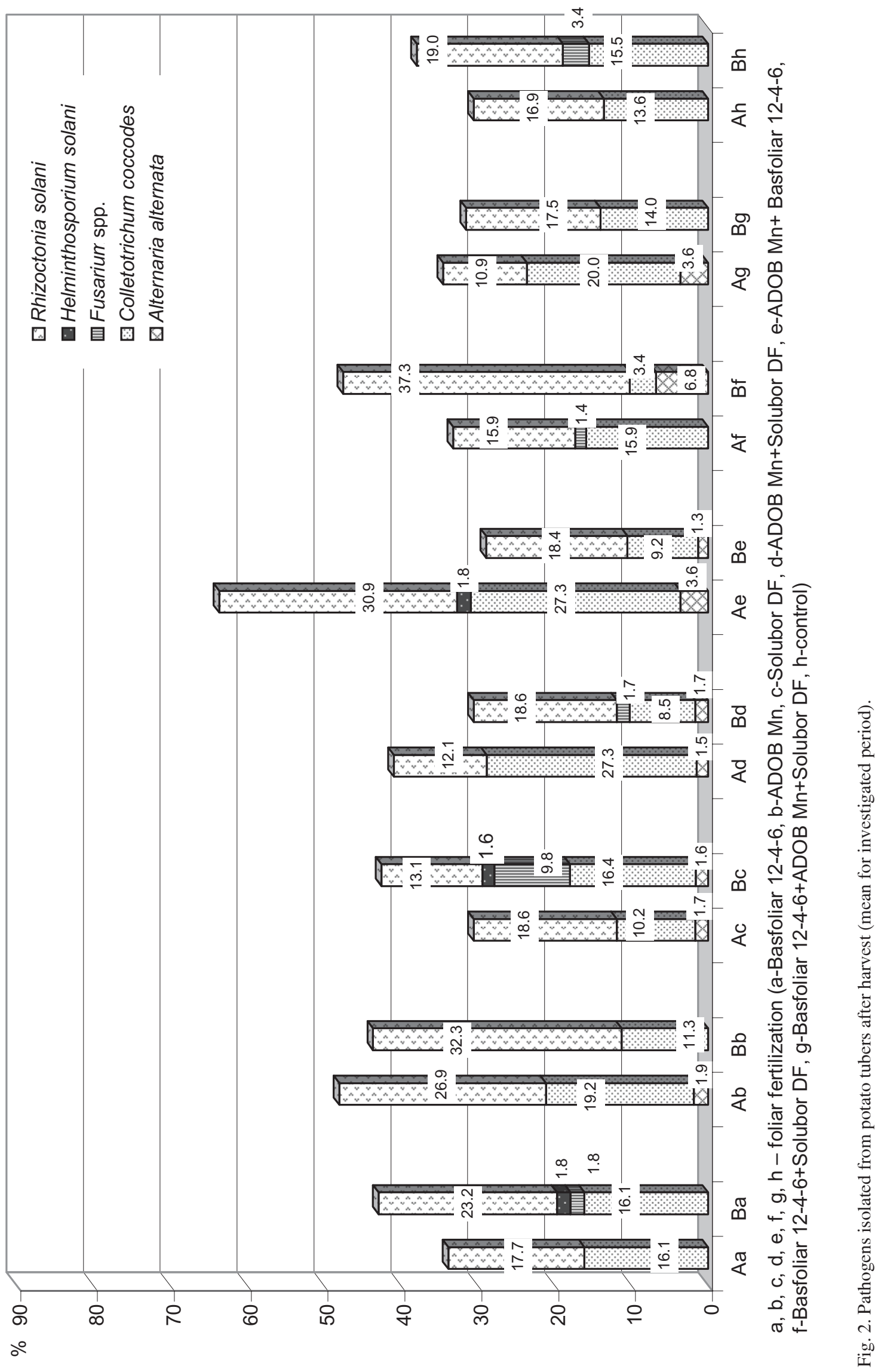




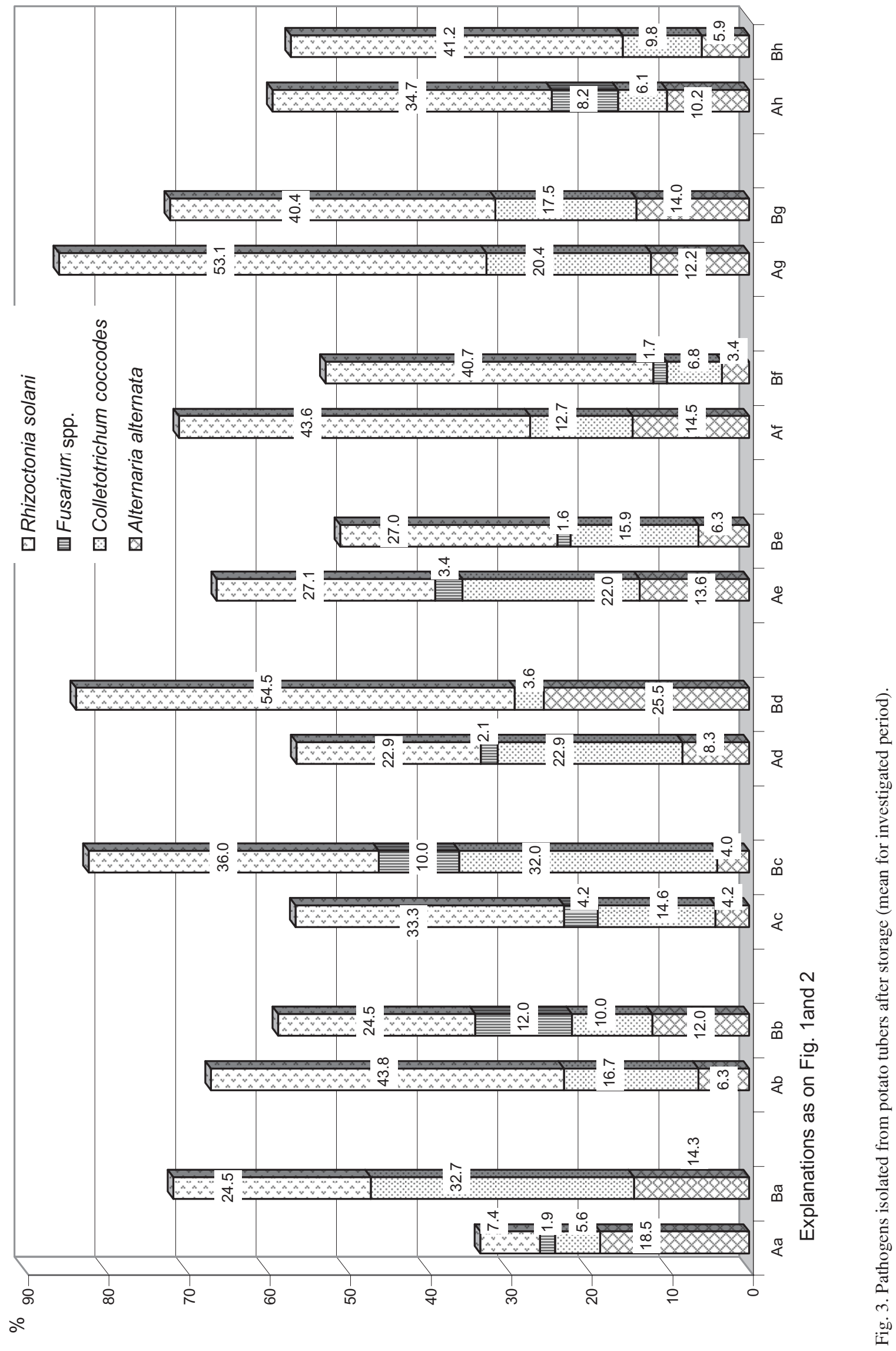


A different tendency was reported with respect to fungi of the genus Fusarium, which more frequently colonized newly-harvested and stored tubers in treatment B (with higher mineral fertilization levels) than in treatment A(with lower fertilization levels). Their greatest abundance (10\% to $12 \%$ ) was noted in stored tubers in treatment B with the foliar fertilizers ADOB Mn and Solubor DF (Fig. 3), and in newly-harvested tubers in the treatment involving the application of Basfoliar 124-6 and Solubor DF as well as in the control treatment. According to reference data (K u r z a w iń s k a , 1997; E s f a h a n i, 2006; L o i veke, 2006; P e ters et al. 2008), among members of the genus Fusarium such species as $F$. avenaceum, $F$. culmorum, $F$. oxysporum, $F$. sambucinum, $F$. solani are most often the causative agents of potato tuber dry-rot. They may penetrate into potato tuber tissues directly or as a result of mechanical damage during harvest (Choros zew s ki, 1988). Depending on pathogen virulence and cultivar susceptibility, these fungi produce various amounts of mycotoxins dangerous for humans and animals ( $\mathrm{S} \mathrm{ch} \mathrm{u} \mathrm{lt} \mathrm{z}$ et al. 2007).

The species Alternaria alternata was not abundant in stored tubers, and it was absent in some treatments, including in the control one. After five-month storage, the highest number of isolates was obtained in treatment $\mathrm{Bd}(25.5 \%)$, and the lowest - in treatments $\mathrm{Bc}$ and $\mathrm{Bf}$ (around 4\%). The impact of NPK fertilization on the occurrence of this fungal species remains ambiguous. K u mar et al. (1983) demonstrated that high rates of mineral fertilizers, including nitrogen, have a negative effect on plant infection by fungi of the genus Alternaria. O s o w s k i (2005) pointed to an inhibitory effect of combined Basfoliar 12-4-6 and fungicides treatment on plant infection by the above fungi. Laboratory tests performed by B lachińs ki et al. (1996), Feng and Z heng (2006) showed an inhibitory effect of potassium on mycelium growth and the germination of $A$. solani conidia.

\section{CONCLUSIONS}

1. Pathogens were more frequently isolated from potato tubers after storage than after harvest.

2. Mineral soil fertilization with higher NPK rates contributed to the development of pathogens.

3. The foliar application of mineral fertilizers had varied effects on the occurrence frequency and abundance of the pathogens in fungal communities colonizing potato tubers.

\section{REFERENCES}

Andrivon D., Luc as J. M., Guerin C., Jou an B., 1998. Colonization of roots, stolons, tubers and stems of va- rious (Solanum tuberosum) cultivars by the black-dot fungus Colletotrichum coccodes. Plant Pathol. 47: 440-445.

A rx von J. A., 1970. The genera of fungi sporulating in pure culture. Verlag von J. Cramer.

B ernat E., 2005. The occurrence of black scurf (Rhizoctonia solani) on tubers of some potato varieties. Biul. IHAR. 237/238, 195-199. 5 ref.

Blachiński D., Shteiberg D., Dinoor A., Kafkafi U., Sujkowski L. S., Zitter T. A., 1996. Influence of foliar application of nitrogen and potassium on Alternaria diseases potato, tomato and cotton. Phytoparasitica, 4: 281-292.

B olig łow a E., 2003. Wpływ dolistnego dokarmiania ziemniaka (roztworem mocznika i nawozami wieloskładnikowymi) na plon, jego strukturę, zdrowotność i trwałość przechowalniczą bulw. / Effect of foliar fertilizers on potato yield, its structure, wholesomeness and storage life of tubers. Acta Agrophys. 85: 99-106.

B o o th T. C., 1971. The genus Fusarium. Commonwealth Mycological Institute Kew Surrey, England.

Choroszewski P., 1988. Warunki infekcji bulw ziemniaka przez grzyby z rodzaju Fusarium. / Fungi occuring on the tubers with dry rot symptoms. Biul. Inst. Ziem. 43: 105-112.

Cwal in a-A mbroziak B., 2002. Grzyby zasiedlające bulwy ziemniaka (Solanum tuberosum L.) bezpośrednio po zbiorze i po przechowywaniu. / Fungi colonizing potato tubers (Solanum tuberosum L.) after harvest and after storage. Acta Agrobot. 56 (2): 133-140.

Cwalina-A mbroziak B., Czajka W., Bogucka B., Trojak. A., 2007. Dolistne nawożenie ziemniaka a zbiorowisko grzybów chorobotwórczych zasiedlających nadziemne części roślin. / Effect of foliar fertilization of potato on a pathogenic fungal community colonizing the aboveground parts of plants. Prog. Plant Protection. / Post. Ochr. Roślin, 467 (2): 73-77.

Czajka W., Cwalina-Ambroziak B., Czajka M., Fabisiewicz M., 1999. Porażenie bulw ziemniaka patogenami w zależności od nawożenia mineralnego./ Infestation of potato tubers by pathogens in relation to mineral fertilization. Prog. Plant Protection. / Post. Ochr. Roślin, 39: 852-855.

D a v i s J. R., 1981. Black dot. In: Compendium of Potato Diseases. Ed. W. J. Hooker. Am. Phytopath. Society: 55-56.

Domsch K. H., Gams W., Anderson Traute-Heidi, 1980. Compendium of Soil Fungi. Academic Press, A Subsidiary of Harcourt Brace Jovanovich Publishers, London, New York, Toronto, Sydney, San Francisco, 859.

E11 is M. B., 1971. Dematiaceus hyphomycetes. Commonwealth Mycological Institute Kew Surrey, England.

Esfah an i M. N., 2006. Present status of Fusarium dry rot of potato tubers in Isfahan (Iran). Ind. Phytopath. 59 (2): 142-147.

Feng W., Zheng X., 2006. Control of Alternaria alternata by cassia oil combination with potassium chloride or sodium chloride. J. App. Microbiol. 101 (6): 1317-1322. Ind. Phytopath. 59 (2): 142-147. 
Haberland R., 2000. Do potatoes need trace element fertilizer? Kartoffelbau, 51 (6): 260-264.

Hoitink H. A. J., B oehm M. J., 1999. Biocontrol within the context of soil microbil communities a substratedependent phenomenon. Annu. Rev. Phytopathol. 37: 427-446.

Honeycutt C. W., Clapham W. M., Leach S. S., 1996. Crop rotation and $\mathrm{N}$ fertilization effects on growth, yield and disease incidence in potato. American Potato J. 73: 45-62.

J a błoń s k i K., 2003. Wpływ dolistnego nawożenia ziemniaka nawozami dolistnymi ADOB na plon roślin i jego strukturę oraz porażenie bulw chorobami. / Influence of ADOB foliar fertilization to potato leaves on the yield structure and tuber infestation with pathogens. Acta Agrophys. 85: 137-143.

K a p s a J., 2002. Możliwości ograniczania dawek fungicydów przez dodatek Insolu $7 \mathrm{w}$ ochronie plantacji ziemniaka przez Phytophthora infestans (Mont.) de Bary. / Possibilities of reduction of fungicide doses for control of late blight using Insol 7. Zesz. Nauk. AR Krak. 387 (82): 75-79.

Kozera W., Nowak K., Majcherczak E., Barczak B., 2006. Effect of foliar fertilization with microelements on the content of macroelements in potato tubers. J. Elementol. 11 (1): 29-34.

Ku ma r R., Gupta J. S., Shah A., 1983. Effect of nutrition on the incidence of early blight disease and yield of potato. Indian Phytopathol. 36: 405-406.

Kurzawińska H., 1997. Fungi occurring in potato tubers with dry rot symptoms. Phytopathol. Pol. 13: 79-84.

L oiveke H., 2006. Incidence of Fusarium spp. on several field crops in Estonia and their toxicity towards Bacillus stearothermophilus. Agronomy Res. 4 (Special Issue): 273-280.

O s ow s k i J., 2005. Możliwość wykorzystania cynku w ochronie ziemniaka przed alternariozą. / A possibility to use zinc in protection of potatoes against early blight. Biul. IHAR 237/238: 187-193.

Pastucha A., 1999. Ochronne działanie mikroorganizmów antagonistycznych w ograniczeniu występowania chorób korzeni soi (Glycine max (L.) Merrill). / Protective effect of antagonistic microorganisms in limiting soyabean (Glycine $\max ($ L.) Merrill) root diseases. Ann. Univ. Mariae Curie-Skłodowska, sec. E, 7: 119-135.

Peters J. C., Lees A. K., Cullen D. W., Sullivan L., Stroud G. P., Cunnington A. C., 2008. Characterization of Fusarium spp. responsible for causing dry rot of potato in Great Britain. Plant Pathol. 57: 262-271.

Repsiene R., Mineikiene E. V., 2006. The influence of meteorological conditions and different agricultural systems on the spreading of potato cv. 'Mirta' tuber diseases and their yield. Zemes ukio Mokslai. 2006. 3, 16-25. 38 ref.

Rębacz K., B orówczak F., 2007. Porażenie patogenami bulw ziemniaków odmiany Bila w zależności od deszczowania, technologii uprawy i nawożenia azotowego.
/ Pathogen infestation of potato tubers of Bila cultivar depending on irrigation, cultivation technology and nitrogen fertilization. Prog. Plant Protection. / Post. Ochr. Roślin, 47: 294-298.

Ritchie F., McQuilken M., Bain R., 2006. Effects of water potential on mycelial growth, sclerotial production, and germination of Rhizoctonia solani from potato. Mycolog. Res. 110 (6): 725-733.

Schultz B., E1ner F. M., Gossmann M., Buttner C., 2007. Investigation into virulence and mycotoxin formation of the dry rot causing pathogen Fusarium sambucinum on potatoes. Mycotoxin Res. 23 (2): 78-84.

S zutkow ska M., Lut o m ir sk a B., 2002. Wpływ środowiska i niektórych czynników agrotechnicznych na porażanie się bulw ziemniaka parchem zwykłym. / Influence of environmental conditions and agriculture factors on tuber infection with Streptomyces scabies. Biul. IHAR 221: 153-166.

Tsror /Lahim/L., Erlich O., Hazanovsky M., 1999. Effect of Colletotrichum coccodes on potato yield, tuber quality, and stem colonization during spring and autumn. Plant Disease 83 (6): 561-565.

Weber Z., 1990. Wstępna ocena przydatności nowych fungicydów do wiosennego zaprawiania sadzeniaków ziemniaka. / Preliminary estimation of the usefulness of new fungicides for spring dressing of potato seedtubers. Phytopath. Pol. 11: 212-218.

Z a r z y ck a H., 1990. Grzyby jako pasożyty okolicznościowe na materiałach hodowlanych ziemniaka w Młochowie. / Facultative fungal parasites on potato breeding material in the Institute for Potato Research at Młochów. Phytopath. Pol. 11: 39-50.

\section{Wpływ nawożenia mineralnego na grzyby zasiedlające bulwy ziemniaka (Solanum tuberosum L.) po zbiorze i po okresie przechowywania}

\section{Streszczenie}

$\mathrm{W}$ pracy przedstawiono wyniki trzyletniego doświadczenia ścisłego w Bałcynach z uprawą późnej odmiany ziemniaka Jasia. Badano wpływ poziomów nawożenia mineralnego: A (N $80 \mathrm{~kg} \times \mathrm{ha}^{-1} \mathrm{P} 80 \mathrm{~kg}$ $\left.\times \mathrm{ha}^{-1} \mathrm{~K} 120 \mathrm{~kg} \times \mathrm{ha}^{-1}\right)$ i B $\left(\mathrm{N} 120 \mathrm{~kg} \times \mathrm{ha}^{-1} \mathrm{P} 144 \mathrm{~kg}\right.$ $\times$ ha $^{-1} \mathrm{~K} 156 \mathrm{~kg} \times \mathrm{ha}^{-1}$ ), a także nawożenia dolistnego (Basfoliar 12-4-6, ADOB Mn i Solubor DF) na skład ilościowy i jakościowy grzybów zasiedlających bulwy ziemniaka. Izolacje grzybów prowadzono bezpośrednio po zbiorze bulw i po 5-miesięcznym okresie przechowywania. Wyrosłe po 7-dniowym okresie inkubacji kolonie grzybów przeszczepiano na skosy agarowe w celu późniejszej identyfikacji mikroskopowej.

Podczas całego okresu badań więcej grzybów chorobotwórczych otrzymano z bulw ziemniaka analizowanych po przechowywaniu niż z bulw po zbiorze, 
a największy ich udział zanotowano w 2004 r. Wśród nich najczęściej izolowanym był gatunek Rhizoctonia solani, rzadziej Colletotrichum coccodes i Alternaria alternata. Patogeny z rodzaju Fusarium oraz gatunek Helminthosporium solani wyosobniano nielicznie. Przeważającą liczebność patogenów w kombinacji z nawożeniem mineralnym doglebowym z niższą dawką NPK zanotowano w 2004 r. w obu terminach po zbiorze i przechowywaniu oraz w 2005 r. po zbiorze. W pozostałych analizowanych terminach patogeny częściej izolowano z bulw w kombinacji z wyższą dawką NPK.
Najwięcej patogenów z bulw po zbiorze uzyskano w kombinacji z zastosowanym nawozem dolistnym ADOB Mn i Basfoliar 12-4-6 łącznie. Po przechowywaniu natomiast patogeny najczęściej kolonizowały bulwy w kombinacji B z nawożeniem dolistnym Solubor DF, Solubor DF i ADOB Mn łącznie oraz w kombinacji A z łącznym stosowaniem nawozów. Liczebność sprawców chorób bulw w pozostałych kombinacjach nawozowych, w tym kontrolnej, kształtowała się na zbliżonym poziomie. 
